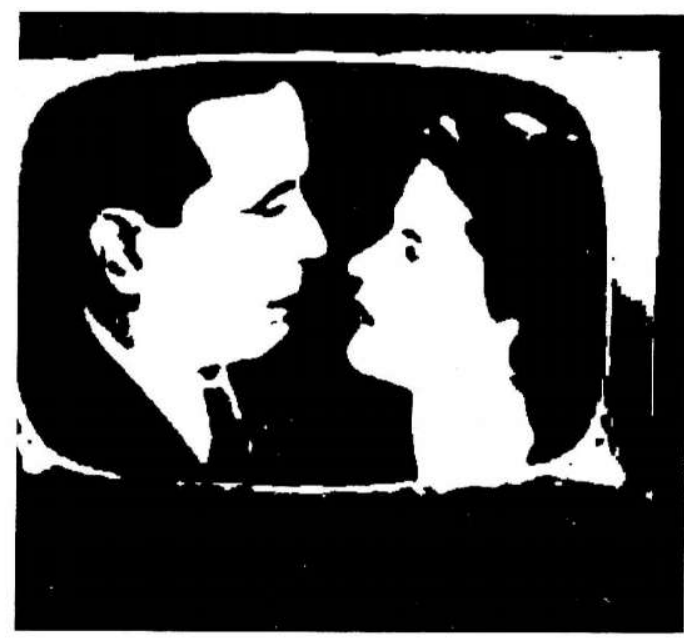

\title{
Watching Dallas: Os primeiros passos da trajetória intelectual de len Ang
}

Watching Dallas: The first steps of the len Ang's intellectual path

Ana Carolina D. Escosteguy

Dra em Comunicação e professora na PRC/RS

E-mail: carolad@pucrs.br

Bárbara Gravino Nassif

Resumo

0 objetivo deste artigo é apresentar um apanhado sobre a pesquisa realizada por len Ang, nos anos 1980, sobre a soap opera Dallase seus telespectadores. A problemática principal diz respeito à identificação de algumas características de Dallas e a sua relação com o prazer do espectador.

Palavras-chave:

1 Não cabe aqui apresentar uma definição para História das Idéias e/ou História Intelectual; para tal, ver Silva (2003).

${ }^{2} 0$ projeto de pesquisa que desenvolvemos atualmente, intitulado Contribuições teóricometodológicas dos estudos culturais para o campo da comunicação (2003-2005), financiado pelo $\mathrm{CNPq}$, tem como objetivo reconstituir diversas trajetórias intelectuais na área.

${ }^{3}$ Decidimos publicar esta breve apresentação da pesquisa em virtude de uma grande carência de textos em português sobre o assunto e quase desconhecimento no meio brasileiro da trajetória da pesquisadora len Ang e seus trabalhos. Buscamos, também, aguçar o interesse pela autora $e$ sua obra.

${ }^{4} \mathrm{~A}$ primeira edição em inglês é de 1985 , sendo que a publicação em holandês é de 1982.
Desnecessário dizer que os estudos de mídia ainda se encontram carentes de obras e mesmo de ensaios que apresentem histórias intelectuais ou que se identifiquem sob o rótulo mais antigo de história das idéias ${ }^{1}$. Alcançar uma sistematizaçāo teórica desse gênero pressuporia a realizaçáo de um dicionário de nomes próprios com biografias intelectuais, apresentação e comentário de uma obra ou até mesmo do conjunto da produção do autor escolhido. A tentativa aqui se insere nesse projeto ${ }^{2}$, mas é um passo inicial e ainda muito precário. Neste momento, apresenta-se a pesquisa Watching Dallas, ${ }^{3}$ de Ien Ang, realizada no início dos anos 1980 e publicada originalmente em holandếs ${ }^{4}$, como uma contribuição àqueles que se dedicam à pesquisa de recepção, sobretudo à vertente vinculada aos estudos culturais.

\section{A paixão pelo objeto}

Nascida na Indonésia, em 1954, Ang imigrou com sua família, aos 12 anos, para a Holanda, onde recebeu uma educação clássica. Formou-se em psicologia pela Universidade de Amsterdã, onde fez também seu mestrado e doutorado, época em que teve contato com os estudos culturais. Sua dissertação de mestrado, Watching Dallas, além de inovar em termos da problemática da investigaçäo, é também uma tentativa da autora de mostrar que é possível realizar uma pesquisa cujo objeto de estudo seja do envolvimento do pesquisador. A própria Ien Ang assume gostar de Dallas, tendo transformado essa preferência em seu problema de pesquisa. No entanto, essa condição não prejudica sua análise.

A originalidade do estudo de Ang reside na proposta de investigar o fenômeno do prazer, em especial "os mecanismos através dos quais o prazer é despertado" (ANG, 1985, p.9) e a "relaçăo entre prazer e ideologia" (ANG, p. 11), de uma produçāo norte-americana, Dallas, em evidência tanto na Europa quanto nos Estados Unidos no momento do estudo, entre 1978-1981.

Dallas foi uma soap opera de grande sucesso não só na televisão americana como em vários países do mundo. Produzida no final dos anos 1970, retratava a vida de uma família texana de classe alta, moradores de um rancho e donos de uma fábrica de óleo. A família era composta por sete pessoas: Jock Ewing, o patriarca, e sua esposa Ellie; os filhos John Ross (J.R.) e Bobby, com suas esposas Sue Ellen e Pamela, respectivamente; e Lucy, filha de outro irmão, Gary, que não aparece na trama. Cada personagem exerce um certo papel na história, com características e traços bem marcantes, como a crueldade de J.R., a constante depressão de Sue Ellen, Bobby e Pamela como o casal perfeito, dentre outros. Esse "retrato" de uma família americana correu o mundo e era transmitido no horário nobre em diversos países, conseguindo uma audiência impressionante e legiōes de fâs.

Ien Ang decide pesquisar o porquê do grande sucesso do programa, tentando descobrir por que tantas pessoas o assistiam, 
de onde vinha o prazer de assisti-lo. Para encontrar material para análise, Ang colocou um pequeno anúncio ${ }^{5}$ em uma revista feminina holandesa, Viva, pedindo para que the escrevessem cartas dando opiniōes sobre Dallas. Como resposta recebeu 42 cartas desse conjunto, 39 eram de mulheres - que utilizou como base para seu trabalho. As cartas variavam de dimensão, de poucas linhas até dez páginas, e o resultado da análise rendeu o livro chamado Watching Dallas soap opera and the melodramatic imagination, editado pela Routledge, Londres, em 1985.

\section{A relação da pesquisa com o contexto}

Os estudos culturais têm tentado dar conta de diversos fenômenos, tanto culturais quanto políticos, a partir do estudo das relaçóes entre comunicaçăo e cultura. Tanto no Brasil quanto na América Latina, contudo, a contribuição desse campo tem sido excessivamente articulada aos estudos de recepção. Embora tenha sido essa problemática de investigação empírica a que mais tem contribuído para configuração dos Estudos Culturais no nosso território, não se pode desconsiderar que o interesse pela mídia, ainda, dentro do Centre for Contemporary Cultural Studies $^{6}$ (CCCS) - Birmingham, surgiu centrado nos conteúdos da indústria cultural e suas repercussōes na sociedade.

$\mathrm{Na}$ década de 1970, o Grupo de Mídia do CCCS produziu uma série de estudos que teve forte repercussão na história da pesquisa em comunicaçăo no final do século XX. Convém notar, porém, que se trata de uma área que se desenvolveu por meio de uma série de estágios. Houve de início um interesse pelos noticiários de televisão, seguido pela preocupação de incorporar programas mais "populares" e, na sequiência, dada a representaçâo mais substancial das mulheres e de seus interesses, destacou-se um novo foco na programaçāo que funciona sob a rubrica "entretenimento e prazer" em vez de "educaçāo e informação".

Embora năo tenha sido realizada dentro do CCCS nem tenha enfocado prioritariamente o que passa pelos meios de comunicaçāo, a pesquisa de Ien Ang se insere nesse contexto. Trata-se de uma investigaçāo que marcou uma alteração nos rumos dos estudos de mídia, tornando-se mençăo obrigatória nas revisōes de literatura que pretendem dar conta do olhar que vê as audiências como potencialmente ativas, construindo sentidos e interpretaçóes dos produtos midiáticos consumidos.

Portanto, sua pesquisa éinovadora no contexto de seu surgimento, pois, seguindo alguns padrōes desenvolvidos pelo centro de estudos de Birmingham, desloca-se da análise do texto para os relatos da audiência. Além disso, utiliza o conceito de prazer que estava vinculado, na época, aos estudos psicanalíticos de cinema e historicamente associado a análises textuais, para analisar empiricamente as audiências, tipo de pesquisa situada dentro do campo da comunicação de massa.

\section{A pesquisa em si mesma}

Ang começa seu trabalho justificando a escolha do tema e explicando a estrutura básica do programa. A primeira descoberta da autora é a de que há muita ambigüidade em relaçáo à Dallas. muitos gostam, outros odeiam, mas os sentimentos se misturam. Até mesmo quem nāo gosta assiste por curiosidade e fantasia sobre o futuro das personagens. A resposta à principal pergunta de Ang: por que as pessoas assistem Dallas? é inicialmente muito simples: porque sentem prazer ao fazê-lo.

É nesse ponto que o trabalho toma um rumo diferente, buscando descobrir de onde vem esse prazer. Vários autores têm opinióes formadas sobre o prazer obtido dos produtos criados para massas - como éo caso de Dallas. A autora cita, por exemplo, Adorno e Horkheimer, que afirmam que esse prazer é uma sensação falsa, que tudo o que existe é opressão e manipulaçăo. Mas não é possível que milhares de pessoas sintam prazer com um produto que apenas manipula; deve haver um pouco de "prazer real" ao acompanhar Dallas, questiona Ang. Outro autor mencionado pela autora sobre a mesma temática é Bourdieu, que sugere que uma dose de prazer vem de uma associação, um envolvimento emocional ou sensual com o objeto de prazer.
5 "Gosto de assistir ao seriado de TV Dallas, mas seguidamente percebo reações estranhas das pessoas com relação a isso. Alguém gostaria de me escrever e contar por que também gosta ou desgosta de assistir ao seriado? Pretendo incorporar essas reações em minha tese universitária. Favor escrever para ..." (ANG, 1985, p.10).

${ }^{6} 0$ Centro foi criado por Richard Hoggart, professor do Departamento de Língua Inglesa da Universidade de Birmingham, que o dirigiu até 1968. No periodo entre 1968 e 1979 quem assume sua direção é Stuart Hall, que dele participou desde sua fundação. 0 terceiro diretor foi Richard Johnson (1980-1987), seguido por Jorge Larrain (1988-1993). A partir dos anos 1980 , porém, os estudos culturais se expandem geograficamente e a GrãBretanha deixa de ser o centro irradiador. Há evidências, hoje, de vitalidade dos estudos culturais nos Estados Unidos, Austrália, Canadá, África do Sul, Nova Zelândia, Taiwan e mesmo na América Latina. 
Mas o grande sucesso de Dallas não pode ser isolado de todo um contexto social, alerta a autora. O horário que o programa foi veiculado (no horário nobre) já propicia, por si só, um certo prazer. O fato de os outros canais não oferecerem programas mais atrativos também ajuda o sucesso. Muitos assistem Dallas simplesmente por năo terem nada melhor para fazer, e é a emissora que decide qual a programaçăo; o público apenas aceita, ou troca de canal. Mesmo assim, não se pode eximir a grande responsabilidade que o programa em si exerce nesse sucesso todo. $\mathrm{O}$ primeiro passo para se entender Dallas é aceitá-lo com um programa de ficção e compreender que cada receptor tem (ou pensa que tem) uma razão própria para gostar dele ou não. Não há uma opinião homogênea sobre Dallas. Há quem assista pelas personagens, pelo cenário, pelos temas tratados, dentre outros motivos. Mas a maioria aprecia pela associação de tudo isso.

$O$ processo de identificação com a história é essencial para que haja prazer. As personagens exercem papel fundamental, mas, se descontextualizadas, não criam envolvimento com o público. O mundo retratado por Dallas nem parece o que cerca muitas pessoas, já que é um mundo de riqueza eluxúria, mas produzido de tal forma que há uma verossimilhança com o mundo real e, com a inserção das personagens, tal universo passa a ser completamente viável. É interessante observar que, quando a construção é bem feita, o público reconhece o programa como ficção, mas passa a comentá-lo como se fosse realidade, a tal ponto de confundir os atores com as personagens que encarnam.

Contraditoriamente, muitas cartas de receptores que não gostavam de Dallas consideram o mundo do seriado não-realista, com tragédias demasiadamente fantásticas (seqüestros, acidentes de avião, desastres, etc.) ocorrendo com uma mesma família em pouquíssimo tempo. Além do fato de pessoas tão diferentes e com tantos conflitos, como é o caso da família Ewing, continuarem morando na mesma casa, apesar de terem condiçóes financeiras para cada um possuir sua própria moradia.

Enquanto isso, outros acham que o mundo refletido pelo programa é extremamente genuíno. Isso se dá pelo fato de o conceito de "real" não ser único, de depender da realidade social de cada um. Os problemas que surgem na vida de um nem sempre são considerados problemas na vida de outros.

De acordo com Ang, o prazer ou desprazer gerado pelo seriado entre as telespectadoras relaciona-se a questóes de 'realismo' (p.34). Porém, os dois grupos distintos de făs e de críticos do programa cada qual 'investia a noção de 'realidade' com um conteúdo diferente' (p.35). Se aquelas que odiavam Dallas consideravam o seriado 'não-realista', por passar uma 'imagem distorcida da realidade (p.36), as que adoravam o programa julgavam-no realista ao proporcionar uma 'experiência da realidade' (MASCARELLO, 2004, p.51).

Assim, o que faz Dallas parecer tão real, mesmo com suas contradiçôes, é sua "transparência". A técnica de narrativa utilizada faz com que o receptor se sinta presente na história, assistindo tudo através de uma janela limpa, transparente, sem edição, cortes ou maquiagem. A história parece desenrolar-se diante dos olhos do telespectadore, "coincidentemente", a câmera só mostra as cenas que possuem alguma açăo interessante. Esse padrăo de filmagem é ditado por Hollywood e aceito e reconhecido no mundo inteiro.

Segundo Barthes, utilizado como referência importante na pesquisa, um texto pode ser lido em vários níveis. Se virmos Dallas no nível denotativo, não encontraremos motivos para seu sucesso, mas, de forma contraditória, acharemos explicaçóes inclusive para quem não gosta da série. Muitos acham os fatos que se desenrolam na história não-realistas, enquanto o roteiro é um dos principais motivos para o desgosto de outros. Portanto, é no nível conotativo que encontramos a maioria dos fãs. A associaçáo, não com a história em si, mas com os problemas das personagens, mesmo que estes sejam exagerados, é um motivo muito forte para o prazer encontrado. Esse nível de leitura dá

conta de uma atribuiçăo de significados emocionais a Dallas, o que leva a [autora] a chamá-la 'realismo emocional'(...). 
Conforme Ang, a experiência de realismo das fấs de Dallas (...) situa-se no plano emocional: o que é reconhecido como real não é o conhecimento do mundo, mas uma experiência subjetiva do mundo: uma 'estrutura de sentimento' (p.45) (MASCARELLO, p.52).

No mesmo campo dos sentimentos, Dallas é regido pela "estrutura trágica de sentimento", que é exatamente a oscilação entre amor e ódio, felicidade e tristeza, a turbulência constante das emoçóes da soap opera. A "estrutura trágica de sentimento" também é responsável pelo prazer, como uma montanha russa que sempre promete novas emoçóes. Essa expectativa de mudança gera curiosidade e prazer naqueles que a acompanham.

Para entender Dallas é preciso também, diz a autora, classificá-lo pelo seu gênero. $O$ gênero é importante em qualquer texto, pois é por meio dele que o público sabe o que esperar e se prepara para tais emoçôes. Uma soap opera é uma narrativa contínua, com um núcleo central e com episódios que se completam, gerando uma história lógica. A principal diferença entre a soap e a clássica novela é que a primeira não tem previsāo de final e possui personagens principais e secundários, enquanto a novela tem um fim definido e o núcleo é dividido em células menores que oscilam entre principal e secundário. A série distingue-se das duas formas de narrativa por nāo ter uma linearidade. Cada capítulo tem início, meio e fim e pode ser visto separadamente dos outros, que será entendido quase perfeitamente. Uma série também possui, geralmente, uma personagem principal, um herói, que conduz toda a história. Dallas é claramente uma soap opera que necessita de atenção constante para que o contexto seja entendido e absorvido. Como não há um problema central que inicie a trama, não há previsão de final e novos problemas vão surgindo e sendo resolvidos com o tempo, destruindo e restaurando o equilíbrio constantemente.

Para prender a atençāo do público e acentuar o caráter dramático do programa é utilizada uma forma de narrativa bastante interessante, denominada "cliffhanger", o corte brusco no momento de tensão máxima.
No cume emocional é feito um close-up da personagem, que expressa toda a emoçāo, levando o fluxo adiante, e um corte brusco com a frase "to be continued" (continua) para atiçar a curiosidade e a tensāo provocada. Nos próximos capítulos acontecerá a dissolução (ou não) do problema apresentado, e a personagem em questão sofrerá uma mudança ou transtorno emocional.

As primeiras soap operas eram produzidas com cenários esparsos e com elementos visuais mínimos. Já Dallas foi produzida como um filme, com visual chique, cenários rebuscados, roupas e maquiagens exuberantes. Todos esses signos apresentados no programa refletiam o padrão de vida americano, com suas casas e carros maravilhosos, e por si sós já exerciam grande prazer naqueles que assistiam. Nâo foi difícil para Dallas virar símbolo de consumo e prazer.

Em Dallas, cada capítuloé uma "caixa de surpresas" com várias narrativas paralelas, enquanto uma delas, a mais dramática, toma o papel principal. Cada semana uma personagem está no foco da ação, pois o que vale é a comunidade, e nāo a individualidade de cada figura. Um aspecto importante também é a seletividade da soap. Problemas sociais são sempre deixados de fora, tudo o que é mostrado parte de conflitos familiares, emocionais, tragédias, mas nada que possa gerar um pensamento mais profundo sobre o mundo real. As reflexóes aparecem quando problemas dramáticos, como alcoolismo, depressão e câncer, são mostrados na narrativa.

A reflexão também não ocorre dentro de Dallas. As personagens nunca filosofam, pensam na situação do mundo ou nos problemas externos. Suas vidas giram em torno da família e dos problemas que nela surgem. Esão esses problemas constantes que prendem a atenção do público. Espera-se sempre um final feliz, mas ele nunca acontece. Segundo Roland Barthes, a aparente desordem na história dá a impressão de movimento, de que as coisas estão sempre acontecendo e sempre ficando mais complicadas.

A posição que o receptor exerce também é uma forma de prazer. Ele sabe tudo o que está acontecendo em todos os lados da trama, o que lhe dá uma sensação de poder,

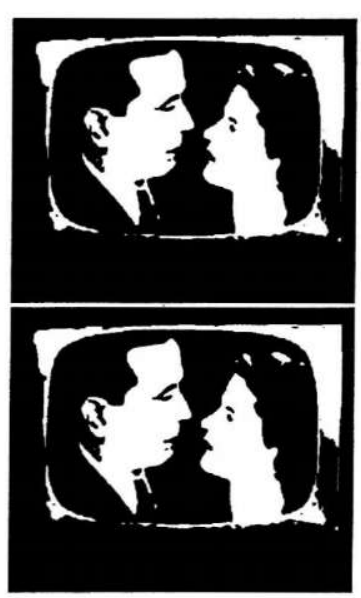




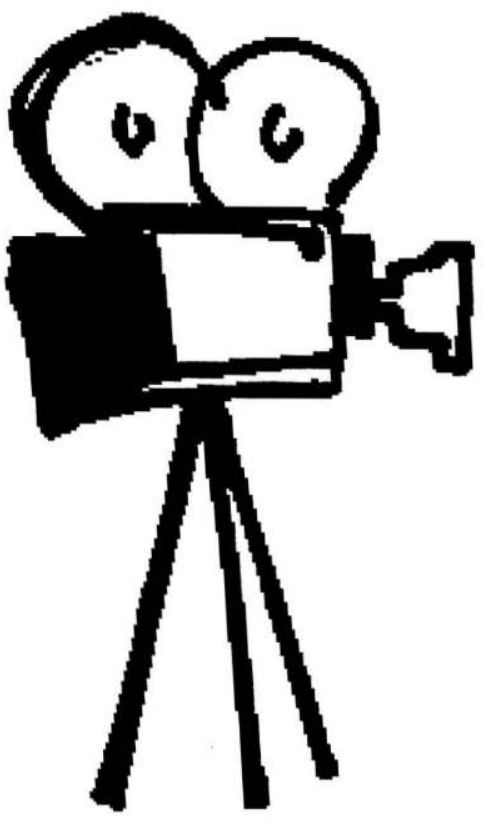

numa posição de onisciência. Essa posição faz com que o receptor possa se envolver com várias personagens ao mesmo tempo, como se as conhecesse mais intimamente, sentidose parte do que acontece.

$\mathrm{O}$ envolvimento torna-se muito importante para que a "estrutura trágica de sentimento" aconteça. Ela só funciona se o receptor consegue se reconhecer e se projetar na personagem, sentindo as mesmas emoçóes que ela. Essa reação acaba gerando a "imaginaçáo melodramática", quando o receptor se desliga de sua vida "chata" e se envolve completamente com aquele mundo fantástico, sem os seus problemas habituais, e pode ser levado pela imaginação e se colocar dentro da trama sem sentir-se culpado por fazê-lo.

A “imaginaçăo melodramática" é mais comum entre as mulheres, não por elas serem mais suscetíveis, mas por terem sido acostumadas com isso, por meio da cultura do mundo em que vivemos. Essa forma de ter prazer não precisa acontecer o tempo todo, há momentos em que ela acontece e torna prazeroso assistir Dallas. E essa não é a única forma de se ter prazer com o programa.

É complicado teorizar o prazer. Muitos receptores assistem Dallas e não sabem qual o motivo específico, apenas gostam e ponto. O prazer é um fenômeno espontâneo, que simplesmente acontece e não se consegue explicá-lo; e, se fosse possível teorizá-lo, acabaria se tornando estático e substancial.

Assim como é difícil explicar por que gostamos de algo, é difícil explicar por que nāo gostamos. $\mathrm{O}$ mesmo ocorre com Dallas. Muitos motivos de desagrado para uns sáo exatamente o que outros gostam. Enquanto alguns receptores não suportam o fato de a soap opera ter uma estrutura fixa, sempre com as mesmas personagens e histórias diferentes, mas com o mesmo pano de fundo, outros consideram isso muito bom, pois assim conseguem envolver-se mais e entender as personagens melhor. Essa ambigüidade está presente em quase todas as cartas analisadas por Ang.

Aqueles que não gostam de Dallas utilizam expressōes, para o julgamento, bastante interessantes, como "claro", "simples", "óbvio", juntamente com "lixo", "bobagem", "ridículo", indicando que não apenas têm essas opiniōes, mas as consideram completamente corretas. Ang mostra-se um tanto quanto desgostosa com essas afirmaçóes, já que seu campo de estudo - os estudos culturais - condena o julgamento de valor de manifestaçóes culturais. As opinióes estão embasadas, em sua maioria, na ideologia da cultura de massa e, mesmo que não saibam exatamente o quê isso quer dizer, acreditam que a cultura de massa é algo ruim e, portanto, isso justifica que Dallas também o seja. Muitos expressam suas opiniōes como se representassem a verdade absoluta.

Mesmo assim, muitos dos que não gostam de Dallas acabam por assisti-la e encontram outra forma de sentir prazer sem culpa: por meio da ironia. Adotando posiçāo de distância e superioridade, criticam e comentam aquilo que acontece de forma irônica, a fim de mostrarem-se longe da história narrada. Uma das cartas analisadas contava que o receptor se divertia muito ao assistir Dallas junto com outras pessoas e que ficava criticando e "tirando sarro" do que acontecia. Nesses casos, a "estrutura trágica de sentimento" nāo cumpre seu papel, pois o melodrama deixa de ser dramático e passa a ser "cômico", já que nâo há identificaçăo.

Gostar de Dallas vira uma espécie de tabu, pois aqueles que assistem, dependendo de sua realidade social, acabam sendo rotulados por isso. Uma das cartas fala que "gostar de Dallas é certo, se você souber que não é realístico e portanto é ruim" (ANG, p.105). Mas ainda há aqueles que não se importam de gostar de produtos da cultura de massa e não precisam se defender contra as reaçóes negativas das pessoas.

Em confronto com a ideologia da cultura de massa temos a ideologia do populismo, que ronda muitos outros receptores. Algumas cartas falam de nunca terem ouvido reaçóes negativas ao seu gosto por Dallas e, aparentemente, vivem em lugares onde a ideologia da cultura de massa não tem tanto poder. A ideologia do populismo consiste exatamente em supervalorizar as manifestaçóes populares e acreditar que o povo, por si só, pode produzir bons resultados e seus julgamentos sobre o que consome săo ideais. As duas ideologias são extremamente contraditórias: a populista parte do conhecimento empírico, enquanto 
a de cultura de massa é basicamente teórica, e ignora completamente o prazer.

A maioria das soap operas é feita especificamente para mulheres, mas isso não ocorre com Dallas. Assuntos como finanças, carros e suspense sāo bem explorados para que prendam também a atenção dos homens. Até mesmo o vilão principal (J.R.), que nas soaps é sempre uma mulher, nesse programa é um homem. Mas, mesmo assim, o maior número de telespectadores é mulher, e a discussão feminista bate de frente com a proposta de Dallas.

No final de seu livro, Ang denuncia uma aliança entre a crítica feminista e a ideologia da cultura de massa, que tende a ver nas mulheres "as vítimas passivas da mensagem enganosa das soap operas" (119). Para uma feminista, o ideal é que a heroína vença toda a opressão da sociedade mediante muita luta e esforço para, então, ter seu final feliz. Numa visão feminista, Dallas é ruim por apresentar mulheres que sāo submissas, que não se revoltam e vivem apenas em função dos seus maridos, sem vontades próprias.

Já no entendimento de Ang, a fantasia é uma dimensão da subjetividade, fonte de prazer porque "coloca a 'realidade' entre parênteses, porque constrói soluçôes imaginárias para contradiçóes reais que em sua simplicidade ficcional (...) estão fora da tediosa complexidade das relaçóes sociais existentes de dominação e subordinação" (ANG, p.135). No entanto, Ang alerta que a experiência dos prazeres melodramáticos nāo deve ser vista como obstáculo ao objetivo feminista de emancipação da mulher, concluindo que:

"a ficçăo e a fantasia, então, funcionam tornando a vida no presente prazerosa, ou ao menos suportável, mas isso, de forma alguma, exclui a atividade ou consciência política radical. Não significa que as feministas náo devam perseverar na produçāo de novas fantasias e lutar por um lugar para a sua existência" (ANG, p.135).

As lutas feministas são importantes, mas não adianta apenas viver em prol de um futuro utópico e não ter prazer enquanto se está vivendo. É fato que as personagens de
Dallas são pouco ativas como mulheres e poderiam fazer mais para melhorar sua situação, mas também se deve deixar de ser tão crítico em relação a tudo e buscar viver com um pouco de prazer.

Realidade e ficção nos produtos midiáticos se juntam para tornar nossas vidas mais prazerosas, e não devemos tomar posiçốes rígidas e radicais em relação a tudo que nos cerca, mas também não podemos nos alienar em relaçāo ao mundo real e seus problemas políticos e sociais. Enfim, a autora reivindica uma posiçāo na qual seja possível perceber a atuaçāo de umà dinâmica ambígua na cultura midiática.

\section{Abstract}

The objective of this article is to present an account of the research done by Ien Ang, in the 80's, about the soap opera Dallas and its spectators. The main point is to identify some characteristics of Dallas that organize the viewer's pleasure.

Key word: cultural sudies, reception, Ien Ang, Dallas

\section{Bibliografia}

ANG, Ien. Watching Dallas: Soap opera and the melodramatic imagination. Londres $\mathrm{eNew}$ York: Routledge, 1985. 148p.

BRUNDSON, Charlotte. The pleasure of a programme like this is not something simple: Ien Ang. In BRUNDSON, Charlotte. The feminist, the housewife and the soap opera. New York: Oxford University Press, 2000. p.147164.

EMANUEL, Susan. Ien Ang, Mirando Dallas. In: BARKER, Martin; BEEZER, Ann (org.). Introducción a los estudios culturales. Barcelona: Bosch Comunicación, 1994. p.29-43.

MASCARELLO, Fernando. Os estudos culturais e a espectatorialidade cinematográfica: Uma abordagem relativista. 2004. 189 f. Tese (Doutorado em Comunicaçāo e Estética) Escola de Comunicaçāo e Artes, ECA, Universidade de São Paulo, São Paulo. 2004. SILVA, Helenice Rodrigues da. A história intelectual em questão. In: LOPES, Marco Antônio (org.). Grandes nomes da História Intelectual. Sāo Paulo: Contexto, 2003. 